Bryn Mawr College

Scholarship, Research, and Creative Work at Bryn Mawr College

Classical and Near Eastern Archaeology Faculty

Research and Scholarship

Classical and Near Eastern Archaeology

1987

\title{
Ancient Greek Women and Art: The Material Evidence
}

Brunilde S. Ridgway

Bryn Mawr College, bridgway@brynmawr.edu

Let us know how access to this document benefits you.

Follow this and additional works at: http://repository.brynmawr.edu/arch_pubs

Part of the Classical Archaeology and Art History Commons, and the History of Art, Architecture, and Archaeology Commons

\section{Custom Citation}

Ridgway, Brunilde S. 1987. Ancient Greek Women and Art: The Material Evidence. American Journal of Archaeology 91:399-409.

This paper is posted at Scholarship, Research, and Creative Work at Bryn Mawr College. http://repository.brynmawr.edu/arch_pubs/8

For more information, please contact repository@brynmawr.edu. 


\title{
Ancient Greek Women and Art: The Material Evidence
}

\author{
BRUNILDE SISMONDO RIDGWAY
}

\begin{abstract}
Ancient Greek women and their relationship to the visual arts are here discussed solely on the evidence of the extant monuments, rather than on the information of the literary sources. Although this review makes no attempt to be complete, several forms of the relationship are explored. The most important is that of women as sponsors of architectural projects; second is that of women as dedicators of statues and other offerings. Finally, the objects meant to be used by women, or those that represent them, are included, although the men of the family might have been responsible for the commission and the funding. The survey follows a chronological arrangement.
\end{abstract}

In the wake of the feminist movement, a great deal of attention has been focused in recent years on women in antiquity. Most such studies, however, have based their conclusions on literary sources, which by their very nature either dramatize or are slanted according to a specific bias. Even those studies that have used contemporary depictions on vases, or other artistic evidence, have often drawn inferences colored by literary knowledge, since many of the painted scenes are less explicit than it may seem, and can be subjected

\footnotetext{
${ }^{1}$ An oral version of this study was delivered as part of a symposium on "Women in the Ancient World" held on 1 February 1986 at Trinity University, San Antonio, Texas. I am indebted to Prof. C. Valone for her invitation to participate in the symposium and for her suggestion that I address the issue of Greek women as patrons. In keeping with my archaeological training, I tried to approach the topic from the tangible evidence alone, using literary sources only as supporting information. Since delivering the paper, I have received several requests for my text, and I have therefore attempted to put it into article form, although without the help of the many illustrations which accompanied the original presentation; it must still be considered in the nature of comments rather than a thorough study, and primarily useful for pointing the way for potential future research.

For a helpful collection of literary sources on women, see, for instance, M.R. Lefkowitz and M.B. Fant, Women's Life in Greece and Rome (rev. ed., Baltimore 1982). But tragedies, historical accounts, and legal records are likely to deal only with extreme cases, and not with common, everyday life. For interpretation of scenes on vases see, e.g., E. Keuls, The Reign of the Phallus (New York 1985), but that different interpretations are also possible is shown, e.g., by G.F. Pinney, "Money-Bags?" $A J A 90$ (1986) 218. For a more moderate approach see also A. Cameron and A. Kuhrt eds., Images of Women in Antiquity (Detroit 1983); I owe this reference to R. Hamilton, to whom I am grateful also for
}

to more than one interpretation. My own task is much more limited in scope, since I do not plan to write specifically on the status of women in ancient Greece; yet the resultant picture may lead to a more balanced view of women's role in their society. What I attempt to do is to draw together a sample group of extant monuments that can be demonstrably connected with women in various ways. Women may have either commissioned or dedicated the items in question; they could have simply used them, or even have been the subject represented on and by them. This last areawomen as depicted in the visual arts-is, of course, too extensive for the scope of a brief survey which makes no claim to completeness. Women as artistic subjects, therefore, will be included only as a way of suggesting their relative importance, thus fleshing out what to me is the more interesting aspect of this research, women as patrons of art and architecture. ${ }^{1}$

Obviously, if by patronage one visualizes the complex relationships of Renaissance women with artists and poets, no such condition seems to have existed in ancient Greece, at least before the Hellenistic period. Even the more limited role played by Roman women

many helpful comments. Other useful studies are M.R. Lefkowitz, Heroines and Hysterics (New York 1981) and S.B. Pomeroy, Goddesses, Whores, Wives, and Slaves (New York 1975); in the latter, however, the archaeological evidence, because of the compass of the study, has been condensed and simplified to the point of being occasionally misleading (e.g., p. 46, on Archaic Attic gravestones of women; not only is there some evidence that stelai just for women existed, but no grave relief, to my knowledge, shows a woman with a warrior).

In my text, all dates should be taken as B.C., unless otherwise specified. Reference has been made to general handbooks or sources of illustrations, to facilitate consultation. The following abbreviations are used throughout:

Boardman J. Boardman, Greek Sculpture. The Archaic Period (London 1978).

Jeffery L.H. Jeffery, "The Inscribed Gravestones of Archaic Attica," BSA 57 (1962) 115-53.

Lazzarini M.L. Lazzarini, "Le formule delle dediche votive nella Grecia arcaica," MemLinc, ser. 8, vol. 19 (1976) 47-354.

Raubitschek A.E. Raubitschek, Dedications from the Athenian Akropolis (Carnbridge, Mass. 1949).

Ridgway B.S. Ridgway, The Archaic Style in Greek Sculpture (Princeton 1977). 
in the dedication of buildings and monuments easily surpasses that of their Greek counterparts. On the other hand, the Greek evidence is significant in various respects, and seems to exist even for the early periods after the Dark Ages; it also appears to show remarkably little regional variation, despite the fact that Ionian women are invariably assumed to have enjoyed greater freedom and privileges than those of the Greek mainland proper. Inevitably, wealth may have been a factor in producing what monumental evidence we have today, but occasionally we get glimpses of the common woman or the middle-class family, especially within the polis and away from the monarchical centers.

\section{THE NINTH-SEVENTH CENTURIES}

The earliest unequivocal evidence of "patronage" is provided by the over-life-sized statue dedicated by $\mathrm{Ni}$ kandre, which may represent the goddess Artemis. Not only is it remarkable for its size $(1.75 \mathrm{~m}$.), but especially for the fact that its date, around 650, makes it one of the earliest pieces of Greek large-scale marble sculpture extant and, in all likelihood, one of the earliest made. Given the paucity of monumental carvings at that time, the statue must have been commissioned, rather than being the work of a sculptor looking for a buyer. In fact, the master is not mentioned in the inscription, which however gives the names not only of Nikandre of Naxos, the dedicator, but also of her father Deinodikes, her brother Deinomenes and her husband Phraxos, in that order. After her patronymic, moreover, Nikandre adds of herself: "excellent among others," a boast of self-worth in keeping with the value of her dedication. ${ }^{2}$

The listing of her family connections suggests that Nikandre was a member of the Naxian aristocracy, and it is in the sphere of the wealthy that one expects to find female patrons. In too many cases, however, especially for the early periods, inscriptions are omitted or missing and inferences from the evidence at hand must remain tentative. We can balance this situ-

\footnotetext{
${ }^{2}$ Nikandre: Ridgway 86-87; Boardman 25 fig. 71; Lazzarini cat. no. 157 . Cf. also Lazzarini no. 726 , for a midsixth century dedication of an agalma on Paros (to Artemis) by Telestodike, who calls herself mother of Asphalios and daughter of Thersileos, but does not name her husband.

${ }^{3}$ For publication of the grave, $\rightarrow$ E.L. Smithson, "The Tomb of a Rich Athenian Lady, Ca. 850 B.C.," Hesperia 37 (1968) 77-116; cf. also Smithson, "The Grave of an Early Athenian Aristocrat," Archaeology 22 (1969) 18-25. For a discussion of connections between person buried and shape of container, see the Hesperia article, p. 81 and n. 19a, where, however, the small neck amphora is considered an unlikely indication of a male child. For further comments on
}

ation, nonetheless, with some finds from earlier female burials that attest to the honors paid to women. One is the cremation grave of a "Rich Athenian Lady" found some years ago in the Agora of Athens. A date around 850 is suggested by the Geometric pottery placed in the rock-cut cist, the ash urn as well as the burial gifts. The urn is a belly amphora, a vessel often found associated with female remains; among the gifts is a neck amphora of much smaller size, which may imply a male child, and perhaps even death in childbirth. ${ }^{3}$ That the main occupant of the grave was a woman is confirmed by anthropological analysis of the bones and by the presence of faience and gold jewelry, some of it with sophisticated granulation, which bespeaks contacts with the Near East and a degree of wealth hitherto unsuspected for Athens of the ninth century. Even more significant of female importance, since the object was meant for use by a woman, is another find among the grave goods: a large terracotta chest/pyxis surmounted by five ovoid shapes. These have been interpreted as models of granaries, and as a possible indication of the social standing of the dead lady's family. Although 850 is considerably earlier than the Solonic reforms, an agricultural wealth of 500 medimnoi could be postulated if each model granary were to symbolize a capacity of 100 medimnoi. The family of the woman who owned such a chest would thus belong to the pentakosiomedimnoi who formed the first-ranking class of citizens in Solon's codification. The lawgiver is thought simply to have made official a long-standing measure of family distinction. ${ }^{4}$ If the ranking pertains to men, the elaborate pyxis itself was unquestionably used by, and made for, the woman buried in the grave.

A second instance is provided by one of the most famous among the Dipylon vases, the great belly amphora Athens N.M. 804, of ca. 750 B.C. Not only is the shape appropriate for a female burial, as contrasted with the kraters that may have marked male graves, but the funerary panel at the point of greatest diameter depicts a long-skirted woman lying on the bier among

\footnotetext{
women and belly amphoras, see infra n. 5 (Simon).

${ }^{4}$ The historical references are clearly discussed by Smithson, Hesperia (supra n. 3); see especially p. 96 and entry no. 46 , pls. 24-27, for the granary chest. On p. 83 Smithson comments that the presence of stamp seals in this and other female graves might be taken as indication "that women, too, had responsibilities in economic affairs, though these may have been confined to domestic matters." For two rich female inhumation graves at Eleusis, possibly of priestesses of Demeter, ca. 800, see J.N. Coldstream, Geometric Greece (New York 1977) 78-80: grave Alpha and the Isis grave. I owe this reference to G.F. Pinney.
} 
mourners. Since other such corpses lying in state are depicted on Dipylon vases with clearly separated legs, the suggestion that this impressive and colossal amphora marked the tomb of a woman should be seriously considered. Once again, the vase is too expensive and its manufacture too demanding for the amphora to have been produced without a specific commission, even if ordered by the woman's husband. ${ }^{5}$

Although much more modest, another funerary "vessel" may be mentioned here, because it is unquestionably connected with a woman: the elaborately painted model of a two-room building from the southwest necropolis of Sellada on Thera. The model, filled with scores of miniature pots, was found in 1982, in association with a funerary pyre. Inscriptions on the end of each of the side walls state that the object belonged to Archidike and was made by Andrias (could the name imply a "maker of andriantes," that is, a sculptor?); it was perhaps an elaborate dollhouse taken to the grave by a child. The painted decoration places the model with pottery conventionally dated around 690-650; its size is considerably greater than that of any known building model from that time, and its complexity marks it as a special creation, probably commissioned by a wealthy family. ${ }^{6}$

\section{THE ARCHAIC PERIOD}

Not so much aristocratic wealth as piety may have inspired the dedications by women on the Athenian Akropolis during the Archaic period. The site is one of the best places for such evidence, since most of the marble bases and monuments were buried after being damaged by the Persians in 480 B.C., and during clean-up operations of the sanctuary for later rebuilding. Chances of preservation affect statistical counts,

\footnotetext{
${ }^{5}$ Amphora by the Dipylon Master, Athens N.M. 804, H. 1.55 m.; E. Simon, Die griechischen Vasen (Munich 1976/ 1981) pls. 4-5a, and pp. 30-31, with comments on the identification of the corpse as female. That the pointed chin is not to be taken as an indication of a beard is shown by comparable renderings on other Geometric vases unquestionably depicting women. See also G. Ahlberg, Prothesis and Ekphora in Greek Geometric Art (SIMA 32, Göteborg 1971) 25 , no. 2, fig. $2 a-c$.

${ }^{6}$ Thera model: Ergon 1982, 45-46, pls. $108-\rightarrow$ N. Winter, "News Letter from Greece, 1982," AJA 88 (1984) 55-56, pl. 19.7-8. I owe a sense of relative size to R. Mersereau, A Study of Greek Architectural Models from the Geometric and Archaic Periods, in Comparison with Models from Other Regions, (M.A. thesis, Bryn Mawr College 1986).

${ }^{7}$ These figures are taken from Raubitschek 465, and entire corpus. Dates range from ca. 575 to the mid-fifth century.

${ }^{8}$ These figures are derived from Lazzarini, whose cover-
}

and many inscriptions, besides being incomplete, cannot be safely connected with the object they once accompanied. Yet from a total of 384 dedications, approximately 215 of which were made by men, at least 18 marble bases and pedestals were inscribed for women: nine inscriptions give the woman's name alone, three are of uncertain reading, and only six (possibly four) mention a father or a husband. ${ }^{7}$ According to another count-of dedications from all over the Greek world, ranging from the eighth to the late fifth century -80 of 884 private offerings name women as the donors. Analysis of these totals should take into account the fact that not all votive gifts carry an inscription, and not all inscriptions mention the dedicant. ${ }^{8}$

To return to the Athenian Akropolis, one woman, Mikythe, inscribes a pillar monument, probably for a relief, made by the Parian sculptor Euphron, for both herself and her children, as a tithe, ca. 470-450. ${ }^{9}$ At approximately the same time, a similar dedication is set up by two sisters, Aristomache and Charikleia, the daughters of Glaukinos the Argive. Two daughters may also be mentioned with their parent on a base possibly for a bronze statue, dated ca. 490 by the letter forms of the inscription. ${ }^{10}$ Such joint dedications of family members headed or largely represented by women are attested through the centuries and from a variety of sites. ${ }^{11}$

Among the most intriguing offerings from the Athenian Akropolis is that carved by Archermos of Chios for Iphidike, an Ionian woman who may have set up Nike Akr. 693. Although no join exists between the statue and the inscribed column preserving Iphidike's and Archermos's names, the association is plausible, since Archermos is credited by both literary and monumental evidence with having made the first sculp-

age ranges from the eighth to the fifth century; for a breakdown of women's dedications according to divinity, see $\mathrm{p}$. 169 and notes 1-2; see also pp. 55-56 for general comments on votive objects, inscriptions and named donors.

${ }^{9}$ Raubitschek no. 298; Lazzarini no. 678.

${ }^{10}$ Aristomache and Charikleia: Raubitschek no. 297; cf. his no. 79 (Lazzarini no. 802) where a dedication (of two bronze statuettes) is made for an Aristomache and an Archestrate by their father Kynarbos, ca. 500. Daughters and parent: Phryne and Smik[ythe], Raubitschek no. 93, Lazzarini no. 23.

${ }^{11}$ Cf. also Lazzarini no. 262, an altar dedicated near Eretria by Charigenes and his daughter Eudene, fifth century. To my knowledge, this type of evidence has not yet been fully collected to demonstrate female participation; for an early attempt, see H. McClees, A Study of Women in Attic Inscriptions (New York 1920). A forthcoming issue of Helios edited by M.B. Skinner, on "Women in Antiquity," contains an article by R. Kraemer on the lives of Jewish women based on a survey of epigraphic and papyrological evidence. 
tured Nike. ${ }^{12}$ It is uncertain whether these Archaic statues of winged women already had the meaning of victory surely associated with them in the fifth century, and indeed it would be surprising to have a "foreign" woman set up such a victory symbol on the Akropolis around 530-520; even if another meaning is assumed, the novelty of the representation marks this offering as unusual.

Other meaningful dedications are the marble basins, occasionally quite elaborate, presented to Athena by women either as aparche (first fruits) or as dekate (tithe). ${ }^{13}$ Among the latter is the early fifth-century offering of Smikythe, who explicitly labels herself plyntria (washer-woman). ${ }^{14}$ Whether she should be considered a menial worker of modest means or the wealthy exponent of a domestic cloth industry is debatable, but the former interpretation is perhaps supported by a small bronze shield decorated with a gorgoneion and inscribed to Athena by Phrygia the artopolis (bread-seller). ${ }^{15}$

The shield is obviously appropriate to the receiver rather than to the giver; the connection between washer-woman and water basins can be argued either way, since such perirrhanteria are certainly at home in sanctuaries, as shown by the most elaborate example so far known, from the earliest Temple of Poseidon at Isthmia. ${ }^{16}$ But in general, dedications by women do not differ markedly from those by men, who seem to

\footnotetext{
12 Nike Akr. 693; for the dedication see Raubitschek no. 3, Lazzarini no. 3. For Archermos and the Delian Nike see B.S. Ridgway, "The 'Nike of Archermos' and her Attire," in J. Boardman and C.E. Vaphopoulou-Richardson eds., Chios, A Conference at the Homereion in Chios 1984 (Oxford 1986) 259-74. Cf. also Boardman 71, fig. 103, and Lazzarini no. 825.

${ }^{13}$ For a discussion of these terms see Lazzarini, pp. 87-90 and 90-93, with summary conclusions on p. 171. Aparche seems to be limited to Attic dedications, almost exclusively to those from the Athenian Akropolis, and is used for votive objects bought from personal earnings, through peaceful activities, never for spoils of war, even when the expression becomes more generic. Dekate, to the contrary, can be used for both types of gains, even if gradually it loses its meaning of tithe, and is attested throughout the Greek world. For marble basins on the Akropolis see, e.g., the elaborate example dedicated as aparche by Kallisto shortly before 480 , Raubitschek no. 369, Lazzarini no. 620; and the one by [...kr]ite, Raubitschek no. 348.

${ }^{14}$ Offering by Smikythe, as dekate: Raubitschek no. 380 , Lazzarini no. 666.

${ }^{15}$ That the women who dedicated water basins headed a prosperous domestic textile industry is suggested $\rightarrow \mathrm{M}$. Vickers, "Artful Crafts: The Influence of Metalwork on Athenian Painted Pottery," JHS 105 (1985) 108-28, esp. 124-25. Offering of Phrygia (a foreign woman?): Lazzarini, no. 46 , pl. 1.2 .

${ }^{16}$ Boardman 25, fig. 74. A detailed analysis of this com-
}

have been the primary donors of the famous Akropolis korai, despite the statues' appearance of aristocratic women. ${ }^{17}$ Some objects of personal adornment, however, such as belts, and others with definite feminine connotations, such as mirrors, must have been made primarily for women, and were dedicated by them in numbers. ${ }^{18}$ Among the mirrors, special attention should be given to those supported by a caryatid, usually a peplophoros type, but occasionally other female figures in various attires. It has been impossible to ascertain whether all or any of these caryatids should be considered Aphrodite; some of the most exotic figures, surrounded by sirens and vegetation, would certainly seem plausible candidates for such an identification. Those more simply and modestly portrayed may be generic allusions to the potential users. In a few instances, however, the caryatid is shown-surprisingly-naked or wearing only a brief loincloth, thus recalling the athletic Spartan women who were entitled to participate in sports events and to set up their own victory statues, although none of them has survived. ${ }^{19}$

When caryatid mirrors go out of fashion, around the middle of the fifth century, lidded disks replace them, the cover often adorned with female heads or other imagery appropriate for women's use. I mention one, dedicated by Phila to Eileithyia, because both the giver and the receiver are noteworthy-the latter for her role in childbirth (rather than in love, or even just

plex perirrhanterion, by M.C. Sturgeon, is forthcoming in the volume on the sculptures in the Isthmia series.

${ }^{17}$ For these comments, see Raubitschek 465-66; cf. also Lazzarini 69. For the aristocratic appearance and significance of the korai see L.A. Schneider, Zur sozialen Bedeutung der archaischen Korenstatuen (Hamburg 1975), passim, and esp. 27-29. For a different viewpoint see B.S. Ridgway, "Of Kouroi and Korai-Attic Variety," Hesperia Suppl. 20 (Studies in Athenian Architecture, Sculpture and Topography Presented to Homer A. Thompson, 1982) 118-27, esp. 123-27.

${ }^{18}$ For belts coming from a sanctuary area in Chios see, e.g., J. Boardman, Excavations in Chios 1952-1955, Greek Emporio (BSA Suppl. 6, 1967) 214-21. For inscribed mirrors see, e.g., Lazzarini nos. 52, 71, 91, 194. I omit here discussion of jewelry, since the value of the objects has produced uneven distribution (because of hoarding) and has reduced the chances of preservation. Moreover, the objects per se do not tell us much about their owners.

${ }^{19}$ See L.O.K. Congdon, Caryatid Mirrors of Ancient Greece (Mainz 1981) 13-18, for comments on possible identifications; for a possible Aphrodite see her no. 5; for "athletic" caryatids see her nos. 14 and 26. For statues of female victors, see Paus. 5.16.3, and for women's sports in general, H.A. Harris, Sport in Greece and Rome (New York 1972) 40-41. On women's sports see also B. Spears, "A Perspective of the History of Women's Sport in Ancient Greece," Journal of Sport History 11 (1984) 32-47. 
beauty and health, as one would expect in connection with a vanity object like a mirror), the former for her name, which recurs repeatedly in the monumental evidence and suggests affection for female progeny who would be given such appellation of endearment at birth. ${ }^{20}$

Several mirrors were found in the sacred spring of the sanctuary of Artemis at Brauron, another divinity specifically connected with children and childbirth. The very ritual at Brauron, involving young girls and their statues, is significant for women and female dedications, but the most prominent offerings have left their traces only in inventory inscriptions listing the many garments ritually donated to the goddess by women who had successfully given birth or even on behalf of those who had died in the process. Given the perishable nature of garments, this type of female offering, which may have been among the most popular forms of female gifts, and perhaps among the most luxurious, can only be documented when such inventories have survived, attesting to a practice that goes back at least as early as the time of Homer. ${ }^{21}$

That death in childbirth was a relatively frequent occurrence may be inferred from grave stelai depicting women and children, for which we now turn to our secondary category of evidence. The most numerous series of Archaic gravestones comes from Athens, and on their basis it had been generally assumed that only premature deaths, especially of young men, were accorded elaborate memorial. New finds have shown that not only older persons but even women were commemorated, the latter perhaps more frequently than the extant reliefs would lead us to believe. It has in fact been argued that stone bases preserving cuttings for wide slabs would have held gravestones depicting seated figures, therefore likely to be women, perhaps holding infants, as in the case of the famous Anavyssos

\footnotetext{
${ }^{20}$ M. Brouskari, The Paul and Alexandra Cannellopoulos Museum (Athens 1985) 78, case 108, no. 22. For other instances of the name see infra.

${ }^{21}$ For a comprehensive account of the finds at the Sanctuary of Artemis at Brauron see, e.g., J. Papadimitriou, "The Sanctuary of Artemis at Brauron," Scientific American 208.28 (June 1963) 111-21. For accounts of the ritual see L.G. Kahil, "Mythological Repertoire of Brauron," in W.G. Moon ed., Ancient Greek Art and Iconography (Madison 1983) 231-44, with previous bibliography. For the accounts detailing female garments donated to the goddess see T. Linders, Studies in the Treasure Records of Artemis Brauronia Found in Athens (Stockholm 1972). For the Homeric reference, see Il. 6.303.

${ }^{22}$ Anavyssos stele: Boardman 164, fig. 237. For comments on women's stelai in Archaic Athens see B. Schmaltz, Griechische Grabreliefs (Darmstadt 1983) 161-63.

${ }^{23}$ Lampito base: Jeffery no. 24; cf. also her no. 12 , to Me-
}

stele. ${ }^{22}$ One such base, for Lampito, is signed by the famous sculptor Endoios. ${ }^{23}$ Elsewhere, sculpture in the round may have been used, such as the stunning kourotrophos nursing twins that was found above a grandiose underground tomb at Megara Hyblaia, in Sicily-either a goddess symbolic of fertility and motherhood, or an earthly mother killed in childbirth by her double offspring. ${ }^{24}$

Such sculpture in the round was used also for young women in Athens itself, and was commissioned from major artists of the sixth century, as shown by two monuments by Aristion of Paros and Phaidimos respectively. The first made the statue for Phrasikleia, whose epitaph suggests death before marriage, as does her elaborate headdress, perhaps a bridal crown. The second made the monument for Phile, whose feet alone survive on a stepped base which implies a standing, kore-like figure; the inscription indicates that it was set up by a parent (name lost), and we note once again the daughter's affectionate name. ${ }^{25}$

That name recurs in the partially preserved epitaph for the so-called Brother-and-Sister stele, which commemorates a youth together with his female sibling. The difficult reading of the inscription leaves uncertain whether the "dear mother" (or the mother, Phile) joined the children in death, or the husband, in life, to set up the monument, ${ }^{26}$ but the latter possibility is made stronger by the several dedications made jointly by spouses during the Archaic and later periods. Perhaps most significant is that by Demokydes and Telestodike, who in the late sixth century set up a statue to Artemis on Paros apo koinon, from the common capital, that is, sharing expenses. ${ }^{27}$

Other Archaic monuments may be mentioned under the rubric of uncertain evidence. Women may have set up their own seated images next to those of their husbands along the Sacred Road from Miletos to

lissa, and no. 27, probably for Kleito; cf. also her pp. 149-50. See also Ridgway 166.

${ }^{24}$ NSc 1954, 99-104; E. Langlotz and M. Hirmer, The Art of Magna Graecia (London 1965) pl. 17.

${ }^{25}$ Phrasikleia: Boardman 73, 75, fig. 108a; Jeffery no. 46 and fig. 14; Ridgway 109 and n. 32 with additional bibliography. Phile: Jeffery no. 44; Ridgway 103 and 118 with additional bibliography.

${ }^{26}$ Brother-and-Sister stele, in New York: Boardman, figs. 224.3 and 232; for the most recent discussion see $\mathrm{S}$. Karousou, "Corrigenda sto $A D$ 1976," AAA 14 (1981) 315, col. pl. 1. For the inscription see also Jeffery no. 63, and C.W. Clairmont, Gravestone and Epigram (Mainz 1970) 13-15, no. 1.

${ }^{27}$ Dedication by Demokydes and Telestodike: Lazzarini no. 803; cf. also no. 342 from Lokroi, sanctuary of Persephone, mid-fifth century, by Kaparon and Proxeno. 
Didyma, to judge by the numerous female statues preserved. That the male statues represent human notables and not priests or divinities is shown by the monument of Chares, ruler of Teichioussa, who inscribes it as both subject and dedicator. The female figures found so far are not inscribed, but the occurrence of several such statues, both male and female, in what seems to be a family temenos may strengthen the suggestion. ${ }^{28}$

Family monuments including not only the wife but several female children occur in Samos as early as the mid-sixth century. The so-called Geneleos dedication, named after the sculptor, included the seated matronly mother (inscribed Phileia, a variant of Phile) and the reclining, prosperous father (...arches), flanking three standing daughters of slightly different sizes and attire (two of them preserving their names, Philippe and Ornithe), and a draped youth, fragments of which have only recently been recognized. ${ }^{29}$ Another recent discovery has led to the realization that various offerings made by Cheramyes are part of a single monument, also a series of single figures on a long base and including one male and at least three female statues. The coincidence of having two such monuments on Samos suggests that this type of dedication may have been more common than at first surmised, and reflects a celebration of the family that gloried in the female as much as in the male progeny. ${ }^{30}$

To round out the evidence from the Archaic period, I may mention an object that may have been made for another celebration, a wedding, and perhaps even specifically for the bride: the François Vase. This master-

\footnotetext{
${ }^{28}$ Chares of Teichioussa: Boardman 70, fig. 95; see also Ridgway 125-29. For the recent discovery of a temenos along the Sacred Road, $\rightarrow$ M.J. Mellink, "Archaeology in Anatolia," $A J A 91$ (1987) 21-22. For a possible female dedication of a seated statue (of herself?) see the Hagemo from Arkadia, Athens N.M. 6, Lazzarini no. 410, Ridgway 124.

${ }^{29}$ Geneleos Dedication: Boardman 70, figs. 91-93; Lazzarini no. 166; for the attribution of the male fragments, see E. Walter-Karydi, "Geneleos," AM 100 (1985) 90-104; she restores the male figure as holding flutes and understands the whole group as a family partaking of a ritual meal in the sanctuary of Hera.

${ }^{30}$ The discovery of a statue that can be considered a virtual double of the "Hera of Samos" in the Louvre, as well as of a portion of a long base for a multi-figured group, was announced in April 1985 at a symposium on Archaic and Classical sculpture sponsored by the German Archaeological Institute: H. Kyrieleis, "Neue archaische Skulpturen aus dem Heraion von Samos," in H. Kyrieleis ed., Archaische und klassische griechische Plastik (Mainz 1986). The other pieces now attributed to the same group are: B. FreyerSchauenburg, Samos 11. Bildwerke der archaischen Zeit und des strengen Stils (Bonn 1974) 21-27, no. 6 (Hera in the Louvre), 27-31, no. 7 (kore with hare in Berlin), 95-96,
}

piece of black-figure painting has always been recognized as a cycle of episodes clustering around the depiction of the main scene: the marriage of Peleus and Thetis, parents of the hero Achilles. Although the krater was found in an Etruscan tomb, at Chiusi, it has recently been argued that it was originally made on commission, with the Athenian patron suggesting the decoration. ${ }^{31}$ Yet Thetis was fated to bear a son greater than his father; could such a message have been meant for the prospective groom? Is it perhaps more logical to assume that the patron was the father of the bride? That the marriage of Peleus and Thetis was considered an appropriate subject for a woman's implement is demonstrated by its occurrence on an epinetron by the Eretria Painter, where also such presumably ill-boding subjects as Harmonia and Alkestis appear together with Aphrodite and Peitho. ${ }^{32}$ Yet the object, which protected the thigh in carding wool, was definitely meant for a woman, and perhaps even for a bride, given its decorative allusions.

\section{THE CLASSICAL PERIOD (FIFTH AND FOURTH CEN- TURIES)}

The epinetron by the Eretria Painter can be dated around 425, and is therefore part of our evidence for the fifth century. By and large, however, there are fewer monumental examples from this period.

Aspasia, mistress and then second wife of Perikles, was certainly prominent in Athens, but the one extant herm purporting to be her portrait is probably a Roman fabrication, combining as it does anachronistic traits from different styles. ${ }^{33}$ Similarly, the priestess

no. 49A/B (kouros; its inscription states that it is "a most beautiful statue," perikalles agalma); they had originally been given different dates.

${ }^{31}$ For the suggestion of a wedding commission, see A.F. Stewart, "Stesichoros and the François Vase," in Moon (supra n. 21) 53-74, esp. 69-70. J.P. Cotter, "Political Symposia and Political Vases," AJA 90 (1986) 187, argues against the wedding theory, and believes that the imagery of the vase is more appropriate for an oligarchic symposium.

${ }^{32}$ For illustrations and comments on the epinetron, see Simon, Vasen (supra n. 5) 146-47, pl. 216. I have not included in my discussion vases used in marriage ceremonies, such as loutrophoroi and lebetes gamikoi, since they can occasionally have been used also by men, and in any case are part of rituals that involve couples, rather than women alone. That loutrophoroi could be made also for men, especially as markers of private or state burials, is well known; see, e.g., G. Kokula, Marmorlutrophoren (AM-BH 10, $1984)$ esp. 37 n. 1; C.W. Clairmont, Patrios Nomos (BAR Int. Ser. 161, 1983) 74-85; R. Stupperich, Staatsbegräbnis und Privatgrabmal im klassischen Athen (Münster 1977) 155-62.

${ }^{33}$ Aspasia herm, in the Vatican Museum: see, e.g., B.S. Ridgway, Fifth Century Styles in Greek Sculpture (Prince- 
Lysimache, who was realistically rendered in a statue by the sculptor Demetrios of Alopeke, may have been wrongly identified in a Roman head in Classicizing style; but the Athenian Akropolis has yielded a base which may have supported the original image, and which in any case confirms that priestesses were honored with statues within the sanctuary. ${ }^{34}$ This practice continued throughout the Greek world and through the centuries. Particularly interesting, in this respect, is the mid-fourth century relief panel from an honorary decree (a so-called record relief) showing the Athena Parthenos next to a small worshiping figure who is being crowned by Nike. Since the figure is much smaller than the goddess, it should represent a mortal; the iconographic formula is well known from comparable decrees for men. But in this case a woman is definitely indicated by her attire; she can be further identified as a priestess because of the large temple key that she holds. ${ }^{35}$ A Boiotian grave stele, for Polyxena, may also show a priestess, since the woman lifts a peplophoros statuette with her left hand; her right hand, now empty, once held a metal object which may also have been a temple key of some kind. ${ }^{36}$

In Athens gravestones had disappeared ca. 500, to reappear around the time of the Peloponnesian War. Those extant seem not yet mass-produced and can achieve a high artistic level, like the stele of Hegeso, ${ }^{37}$ but occasionally the representations lend themselves to interpretations which prove erroneous when epitaphs are also present. The stele of Mnesagora and Nikochares, for instance, depicts what could be taken to be a mother playing with her child, but the inscription

ton 1982) 240-41.

${ }^{34}$ Lysimache, and possible identification: Ridgway (supra n. 33) 231-33, with bibliography. For the Akropolis base and its inscription see $I G \mathrm{II}^{2} 3453=\mathrm{II} .3 .1376$; cf. $O J h$ 19-20 (1919) 302-303 and n. 10, fig. 192, first half of the fourth century.

${ }^{35}$ Record relief for a woman: C. Blümel, Die klassisch griechischen Skulpturen der Staatlichen Museen zu Berlin (Berlin 1966) 79, no. 92, pl. 126. For Myrrhine, priestess of Athena Nike, and her monument, see C.W. Clairmont, "The Lekythos of Myrrhine," in G. Kopcke and M.B. Moore eds., Studies in Classical Art and Archaeology (Locust Valley 1979) 103-10. For a mid-fifth century dedication from the Athenian Agora made to Demeter and Kore by Lysistrate (daughter of) Stephanos, priestess of the secret ceremony (propolos arreto teletes), see Lazzarini no. 715. Statues of initiates to the Eleusinian mysteries were also set up in the agora of Athens, e.g., that of Kleiokrateia, by the famous Praxiteles; and those of Physteus of Acharnai and his wife Peisikrateia, dedicated by their son Demopeithides during the second half of the fourth century: H.A. Thompson and R.E. Wycherley, The Agora of Athens: The History, Shape and Uses of an Ancient City Center (Agora 14, Princeton 1972) 153-54; for statues of initiates see also V.J. tells us they are sister and younger brother. The stele of Ampharete closely resembles the Archaic gravestone from Anavyssos, but the epitaph speaks of grandmother and grandchild. ${ }^{38}$ The possibility exists that these works were not made on specific commission, but were chosen from an existing stock that used standard themes likely to be in demand. On the positive side, however, even if no specific "sponsor" can be postulated for such stelai, the very fact that they were made readily available implies greater recognition of women in Athenian society. Such attention increases to the point that during the fourth century the majority of funerary reliefs include at least one or more female figures, and these often in the prominent or most prestigious pose; occasionally, women are shown singly or in isolation, like Demetria and Pamphile who, like virtual statues in the round, appear within a deep naiskos, one of them seated on an unusually elaborate throne. ${ }^{39}$ Other stelai use the paraphernalia of mourning that are deemed appropriate for men, like the gravestone of Silenis, whose akroterion is a siren tearing her breast and lamenting the dead-a formula used especially for poets and orators. ${ }^{40}$

Increasing frequency in the depiction of women can be noted not only in funerary, but also in votive, reliefs. Several, from the early and mid-fourth century, show groups of worshipers confronting divinities, especially Artemis, Apollo, and Leto, or the healing gods. The mortals often appear as couples, occasionally with their children, among whom daughters are at least as numerous as sons, if not more. In cases of single families, the depiction includes more female

Harward, "Two Dedicatory Portraits by Praxiteles," $A J A$ 86 (1982) 268-69.

${ }^{36}$ Polyxena stele: Blümel (supra n. 35) 17-18 no. 6, pl. 12. For the statue base of Niko, priestess of Athena, at Priene, dedicated by her father Menedemos ca. 331, see J.C. Carter, The Sculpture of the Sanctuary of Athena Polias at Priene (London 1983) 251. Also from Priene, in Berlin, is the statue of Nikeso, priestess of Demeter and Kore; see, e.g., C.M. Havelock, Hellenistic Art (rev. ed., New York 1981) fig. 112. Many more such examples could be collected.

${ }^{37}$ Hegeso stele: see, e.g., Ridgway (supra n. 33) 146-48, fig. 107, and bibliography.

${ }^{38}$ Both stelai and their epitaphs are discussed by Clairmont (supra n. 26) 89-92, nos. 22 and 23 respectively, pl. 11.

${ }^{39}$ Demetria and Pamphile: H. Diepolder, Die attischen Grabreliefs des 5. und 4. Jahrhunderts v. Chr. (Berlin 1931) pl. 51.1; see also passim for gravestones with single women; or cf. a stele in Providence, R.I.: B.S. Ridgway, Classical Sculpture (Catalogue of the Classical Collection, Rhode Island School of Design Museum, Providence 1972) no. 17.

${ }^{40}$ Gravestone of Silenis: Blümel (supra n. 35) 35, no. 29, pl. 47. On sirens in general, see $E A A$ s.v. sirena $(\mathrm{H}$. Sichtermann). 
than male members, and the fact may reflect household reality, even if some of the participants should be considered servants and slaves. If female infanticide was current, as is occasionally suggested, these votive reliefs certainly give no supporting evidence for it. ${ }^{41}$ Dedications by women continue apace, not all of them made by priestesses. Particularly interesting is a group of elegant marble statuettes (about one-third life size) given through the years, from the mid-fourth to the mid-third century B.C., and set up on a special base within a structure in a sanctuary of Demeter and Kore on the island of Kos. Each statuette had its own individual base, which carried the inscription mentioning the dedicant, her father, and occasionally her husband. Other such groups from sanctuaries, of both earlier and later date, have been found. ${ }^{42}$

To return specifically to women as sponsors, we encounter for the first time a particular aspect of women's activities: architectural sponsorship, that is, the erection of buildings and structures as civic projects. This form of female patronage was relatively common in the Roman world, but seemed largely unrepresented for Greek times. Several examples, more or less cogent, can however be listed.

Perhaps the most notorious case is that of the courtesan Phryne who offered to rebuild the walls of Thebes, destroyed by Alexander the Great in 335, and wanted them inscribed "Alexander took them down, Phryne re-erected them." That she is not a legendary figure is shown by the fact that, accused of impiety, she was defended by the historical Hypereides, although other anecdotes about this famous woman may be later fabrications. It is not at all plausible, for instance, on the basis of what is known of sculptural practices in the mid-fourth century, and to judge from the forms and proportions of the extant copies, that

\footnotetext{
${ }^{41}$ See, e.g., G. Neumann, Probleme des griechischen Weihreliefs (Tübingen 1979) figs. 29, 30a, 40b, 44b. Some significant votive reliefs from Brauron are still unpublished, but see LIMC 2 (1984) nos. 459, 974, 1127 s.v. Artemis; see also nos. 64, 66, 75, s.v. Asklepios. For an offering of the second half of the fifth century made on Skiros by five men and three women-perhaps members of a club-see Lazzarini no. 316. For female infanticide see, e $\rightarrow$ M. Golden, "Demography and the Exposure of Girls at Athens," Phoenix 35 (1981) 316-31, and S.B. Pomeroy, "Infanticide in Hellenistic Greece," in Cameron and Kuhrt (supra n. 1) 207-22; see esp. pp. 212-13 for the statement that raising more than two daughters was a sign of affluence. A poem by Antipatros of Sidon (Anth. Gr. 7.7.43) relates the boast of Hermokrateia, who gave birth to 29 children and saw them all live, both boys and girls, not killed but protected by Apollo and Artemis, as contrasted with the fate of Tantalos's daughter.

${ }^{42}$ See R. Kabus-Preisshofen, "Statuettengruppe aus dem
}

she posed for Praxiteles when he made the nude Aphrodite for the Knidians-especially since similar stories are told of other artists, other masterpieces of the past, and other courtesans. What seems indisputable, however, is that Phryne dedicated her own portrait and several statues, some by Praxiteles, in various sanctuaries, notably at Delphi and her native Thespiai. At Delphi, her gilded and inscribed image ("Phryne the Thespian, daughter of Epikles") stood between those of Archidamos, King of Sparta, and Philip II of Macedon, thus arousing the criticism of later generations. ${ }^{43}$ Yet she was not the first courtesan to make important dedications to Pythian Apollo: an Archaic inscription has been recovered from the stone base which may have held the bronze obeloi offered, according to Herodotos, by Rhodopis of Thrace. This famous woman is said to have lived most of her life in Egyptian Naukratis, and was apparently credited with having built the pyramid of Mycerinus at Giza; Herodotos, however, comments that she was not rich enough to have done so and, moreover, had lived at the time of Amasis (i.e., ca. 525) and not of Mycerinus. ${ }^{44}$

Equally anecdotal may be the account that Artemisia was responsible for erecting the Maussolleion at Halikarnassos in memory of her husband; the location of the precinct, in the very heart of the city, shows that its construction had been foreseen during the town planning, and therefore while Maussollos was still alive ${ }^{45}$ Moreover, recent excavations have uncovered evidence of previous burials of importance under the fourth-century structure. On the other hand, Maussollos and Artemisia, brother and sister as well as husband and wife, according to Karian custom, seem to have acted in concert in many instances and to have been honored equally as a pair: an honorary decree from Erythrai shows that a bronze statue to Maussol-

Demeterheiligtum bei Kyparissi auf Kos,” AntP 15 (1975) $31-64$, pls. 11-28. Only one of the eight statuettes is dedicated by a man.

${ }^{43}$ On Phryne and her historicity see $R E 20$ (1950) s.v., col. 893-907 (A. Raubitschek). For her portrait at Delphi see Paus. 10.14.4; the dedicatory inscription is mentioned by Athenaeus 13.591B, who also repeats the criticism of Krates the Cynic. For similar tales being told of different artists, see E. Kris and O. Kurz, Legend, Myth, and Magic in the Image of the Artist (New Haven 1979) passim.

${ }^{44}$ Hdt. 2.134-136; E. Mastrokostas, as cited in "Chronique des fouilles," BCH 78 (1954) 133 (Delphes); cf. Lazzarini no. 305.

${ }^{45}$ On the Halikarnassos Maussolleion and the recent excavations, see, e.g., K. Jeppesen, "Zur Grundung und Baugeschichte des Maussolleion von Halikarnassos," IstMitt 27/28 (1977/1978) 169-211; on its sculpture see G.B. Waywell, The Freestanding Sculptures of the Mausoleum at Halikarnassus in the British Museum (London 1978). 
los had been voted for erection in the agora, while a marble one for Artemisia was to stand in the Temple of Athena. ${ }^{46}$ Their siblings, Ada and Idrieus, another instance of brother-sister marriage, had their statues, made by Satyros the Parian, set up in Delphi by the Milesians. ${ }^{47}$ It has recently been suggested that they may have partly funded the Temple of Athena at Priene, whose stylistic affinity with the Maussolleion has now been amply shown. ${ }^{48}$ Certainly Ada, who survived her husband's death, was restored to the Hekatomnid throne by Alexander after the coup by Pixodaros in 340, and even adopted the Macedonian as her son. A most sensitive, colossal head from Priene, similar to others from Halikarnassos in the archaistic arrangement of the forehead curls, may well represent another statue of Ada, set up in proximity to the temple she may have helped to erect. ${ }^{49}$

\section{THE HELLENISTIC PERIOD (CA. 331-31)}

Priene, beyond the occasional statue of and for a woman, has also yielded evidence that a certain Phile held the highest office in the city and was responsible for building a new aqueduct and reservoir. ${ }^{50}$ But it is the Hellenistic queens, more than the common citizens, who are prominent as sponsors and dedicators of civic and religious buildings. Perhaps, as has been suggested, the evidence is more plentiful for this period because, until Alexander's expedition to Asia, the mainland Greeks were hesitant about putting dedicators' names on building facades, be they individuals, cities, or entire regions. ${ }^{51}$ On the other hand, the very atmosphere of the Hellenistic courts encouraged such pro-

\footnotetext{
${ }^{46}$ For general information on the Hekatomnids see J. Crampa, Labraunda. Swedish Excavations and Researches III.2: The Greek Inscriptions (Stockholm 1972) 6; for the Erythrai decree see also Sylloge inscriptionum graecarum $^{3}$ (Leipzig 1915-1924) 168; J.C. Carter, The Sculpture of the Sanctuary of Athena Polias at Priene (London 1983) 27.

${ }^{47}$ Base in Delphi: J. Marcadé, Recueil des signatures de sculpteurs grecs 1 (Paris 1953) 93, s.v. Satyros; cf. also J.H. Jongkees, "Bryaxis or Satyros?" Mnemosyne 11 (1958) 136-38.

${ }^{48}$ Carter (supra n. 46) 30-31, 99-103.

${ }^{49}$ Carter (supra n. 46) 271-76, no. 85, pls. 39-40, 47a, d, and color frontispiece. For a dedication, approximately contemporary, by a royal woman, see the newly found base from Vergina, inscribed to Eukleia by Eurydike Sirra, probably the mother of Philip II of Macedon: AR 29 (1983) 44; $A R 30$ (1984) 47 fig. 82; M. Andronikos, Vergina (Athens 1984) 50, fig. 26.

${ }^{50} \mathrm{~F}$. Hiller von Gaertringen et al., Inschriften von Priene (Berlin 1906) 208. M.R. Lefkowitz, "Influential Women," 49-64 and esp. p. 57, in Cameron and Kuhrt (supra n. 1); see also pp. 223-42, R. Van Bremen, "Women and Wealth," for other examples, including however the Roman period.
}

motion. Architectural gifts by Hellenistic rulers have recently been discussed, but only one, the Arsinoeion, was connected with a woman..$^{52} \mathrm{~A}$ few more can here be mentioned, without any claim to completeness.

The Arsinoeion on Samothrace is certainly the best known. This impressive rotunda, with a diameter of $20 \mathrm{~m}$. and a clear internal span of over $17 \mathrm{~m}$., ranks among the largest round buildings of Greek antiquity. It was dedicated "to the Great Gods" by Arsinoe II either in 281, when she was still the wife of Lysimachos, or perhaps later, when she had married her brother Ptolemy II; in any case, in her inscription over the doorway of the building she proclaims herself daughter of King Ptolemy, before mentioning the husband whose name is now lost. Technical and decorative similarities between the Rotunda and the Propylon of Ptolemy II have also led to the suggestion that the queen may have been "the effective patron of both buildings." ${ }^{33}$ Within the same sanctuary, a large marble structure flanked by smaller rooms and with an Ionic porch on its south side carried on its epistyle an inscription of the second half of the third century B.C. The dedicator, as indicated by the feminine ending of the adjective, was a Milesian woman, whose name is now lost. ${ }^{54}$

A more unusual case, that of a building dedicated by a city to a queen, rather than vice versa, has been revealed by inscribed architectural fragments built into later walls. The Milesians are thus shown to have donated to Queen Laodike a stoa-like structure, which might have stood near the South Market of Miletos. To judge from the letter forms, the queen named is

\footnotetext{
${ }^{51}$ C. Picard, "Sur les dédicaces monumentales apposés en Grèce aux entablements de façades d'édifices sacrés ou civils," in Charisterion eis A. Orlandon 1 (Athens 1965) 91-107, esp. p. 95. I thank Prof. J. McCredie for this reference.

${ }^{52}$ H.A. Thompson, "Architecture as a Medium of Public Relations among the Successors of Alexander," in B. BarrSharrar and E.N. Borza eds., Macedonia and Greece in Late Classical and Early Hellenistic Times (Washington, D.C. 1982) 173-89.

${ }^{53}$ A volume on the Rotunda, within the Samothrace series, is currently in press. See also the discussion by A. Frazer, "Macedonia and Samothrace: Two Architectural Late Bloomers," in Barr-Sharrar and Borza (supra n. 52) 191203, esp. 197-99; cf. pp. 198-99 for the similarity between the Arsinoeion and the Propylon of Ptolemy II. Frazer favors the date between 289 and 281 for the erection of the Rotunda; the later date, around 276, is favored by Thompson (supra n. 52) 179.

${ }^{54} \mathrm{~K}$. Lehmann, Samothrace, $A$ Guide to the Excavations and the Museum ${ }^{4}$ (Locust Valley 1975) 80, building no. 6 on plan. I am again indebted to Prof. J. McCredie for this reference, as well as for that to Salviat, infra n. 59.
} 
probably Laodike II, wife of Antiochos II, which would then suggest a date around $250 .{ }^{55}$ We know that the Seleukids were worshiped as gods by the Milesians, and that a city was also named after the queen, Laodikeia on Lykos. Ephesos, refounded by Lysimachos, was called Arsinoe, while Smyrna, under the same ruler, was renamed Eurydikeia after his daughter. In this last city, another Seleukid queen, Stratonike, was honored after her death as Aphrodite Stratonikis, and the cult of Laodike II was promoted by Antiochos III. ${ }^{56}$ These points are worth mentioning, since notions of Aphrodite-cult and divine honors are usually associated with the Ptolemaic queens, but the Seleukids seem to have been equally proud of their women. ${ }^{57}$

Another queen equally honored was Apollonis, wife of Attalos I, who reigned 247-197. She built at her own expense the urban sanctuary of Demeter at Pergamon, together with its propylon and stoas, and mentioned the fact in the dedicatory inscription. In turn, a temple in her honor was built at Kyzikos by her sons Eumenes II and Attalos II, as a symbol of filial piety. ${ }^{58}$

In conclusion, two more women may be mentioned, although they were not royal in rank. The first, a certain Epie, was repeatedly honored by the city of Thasos for having performed many services and neokoreiai, in a sort of feminine cursus honorum. The stone with the inscribed decrees includes specific mention that she repaired at her expense many temples, but es-

${ }^{55}$ G. Kleiner, Die Ruinen von Milet (Berlin 1968) 66-67. Cf. also the dedication of a (pre-existing?) fountain in the agora of Teos to Queen Laodike, P. Herrmann, "Antiochos der Grosse und Teos," Anatolia 9 (1965) 29-159, esp. pp. 74-75; the relevant decree is dated ca. 203 B.C.

${ }^{56} \mathrm{~J}$. des Gagniers et al., Laodicée du Lycos. Le Nymphée (Quebec, Paris 1969) 2 and notes 2, 4, 5; cf. also 322-23. Stratonike, the wife of Antiochos I and daughter of Demetrios Poliorketes of Macedon, is also known for her many offerings to the sanctuary of Delos where, in 279, for the marriage of her daughter Stratonike II to Demetrios II, she donated crowns to the statue of Apollo and the Charites, a necklace to Leto; other jewelry was given for the marriage of her daughter Phila to Antigonos in 277/6; cf. W.W. Tarn, Antigonos Gonatas (Chicago repr. 1969) 349-50. On the same island, the queen also set up a statue to Arsinoe while Antiochos's wife.

${ }^{57}$ For the Seleukids, see des Gagniers et al. (supra n. 56) 323, notes 1-2. For the Ptolemies, see D.B. Thompson, Ptolemaic Oinochoai and Portraits in Faience (Oxford 1973); see also S.B. Pomeroy, Women in Hellenistic Egypt. From Alexander to Cleopatra (New York 1984), also for dedications of women in Cyprus.

${ }^{58}$ Cf. Picard (supra n. 51) 105. For a lengthy discussion of the Kyzikos Temple see H. Froning, Marmor-Schmuckreliefs mit griechischen Mythen im 1. Jh. V. Chr. (Mainz pecially that she restored the Artemision and built its gateway, on which was to be inscribed: "Epie, daughter of Dionysios, has dedicated the restoration and the construction of the propyleion to Artemis Eileithyia and the people." The date of Epie's activity is uncertain, but may fall around $85 .{ }^{59}$

The second woman was not a builder, but deserves mention because, in a reversal of the standard situation, it is she who erected a statue to "her husband, Dioskourides, son of Theodoros of Myrrhinous, who offered the two silver Delphic tripods that are in the Temple of Apollo, on either side of the entrance, under the archonship of Timarchos in Athens." This reference gives a firm chronology of $138 / 7$ for both Dioskourides' statue and that of his wife, Kleopatra, daughter of Adrastos of Myrrhinous, which still stands on its pedestal in the Delian house today named after the donor, la Maison de Cléopâtre. ${ }^{60}$ Some 50 years earlier, the practice of erecting statues of women had assumed such proportions in Rome that Cato the Censor tried to prevent it by legislation. ${ }^{61}$ From this point onward, the Hellenistic and the Roman strands intertwine to the extent that a clear separation is impossible, and the next chapter on female patrons should be written as part of the history of Rome.

\section{CONCLUSIONS}

Can broader conclusions be drawn from this specific survey of the monumental evidence? The material assembled is so widespread, both in chronological and

\footnotetext{
1981) 40-47.

${ }^{59}$ F. Salviat, "Decrets pour Épié fille de Dionysios: Déesses et sanctuaires thasiens," BCH 83 (1959) 362-97; see esp. p. 374 for reference to a possible female cursus honorum; the dedicatory formula to be inscribed on the propylon is specified in the decree, lines 16-18. For other public honors to a woman, for unspecified reasons, see the inscribed base for a statue (missing) of Thrasea, daughter of Diodotos, set up by the Samians in the second century B.C. (letter forms): H. Kyrieleis, "Ausgrabungen im Heraion von Samos 1980/ 81," AA 1985, 447 no. 3. See also Pomeroy (supra n. 1) 126, and F.W. Walbank, The Hellenistic World (Cambridge, Mass. 1981) 117.

${ }^{60}$ See, e.g., P. Bruneau and J. Ducat, Guide de Délos (Paris 1966) 160-61, no. 119, which includes the text of the inscription.

${ }^{61}$ Cf. Cato's speech on the Lex Oppia, as related by Livy, $34.2-4$, and the comment in Pliny, HN 34.31. The latter text has, however, also been translated as "statues set up by women" by E. La Rocca, Gnomon 54 (1982) 793. The Latin reads "Extant Catonis in censura vociferationes mulieribus statuas Romanis in provinciis poni." The reading of $m u$ lieribus as a dative is perhaps confirmed by the example given by Pliny just after the passage cited (the statue of Cornelia, mother of the Gracchi). In either case the point is significant.
} 
in geographic terms, that any firm deduction is risky. Nonetheless, a few comments can be ventured. It is clear that the Hellenistic period, with its rise of monarchies and its various ethnic components, saw an increased participation of women, especially of queens, in the civic and religious sphere, which is more than amply confirmed by the literary evidence; this conclusion was therefore to be expected. What to my mind is more surprising is the relative importance of women-as sponsors and as "users" of objets d'art-in the early phases, from the eighth to the fifth century. Since much of this evidence comes from Athens, it cannot be assumed that this unexpected picture reflects the freer customs of the Greek East; and the evidence from the Greek West, the Magna Graecian colonies, is largely untapped. It may repay closer scrutiny. The apparent gap during the Classical period proper, the advanced fifth and the early fourth century, needs further investigation. In general, however, the monumental evidence, beyond supplementing the informa- tion derived from literary sources, seems to suggest a greater role of women in public life than hitherto acknowledged. In many Mediterranean countries, until recently, the wife was the "power behind the throne" despite the lack of official recognition and civil rights. Conceivably the same situation obtained in ancient Greece, and the role of the common woman should therefore not be sought in the histories, the trial cases, or even the tragedies. Certainly the Middle and the New Comedy, with their emphasis on romantic love, reflect the emotional importance of young women over that of young men. But it is in the individual dedications, the votive reliefs, the funerary monuments, the statue bases, perhaps even the buildings, that the role of women should be traced, where the likelihood exists for a more balanced, composite picture. ${ }^{62}$

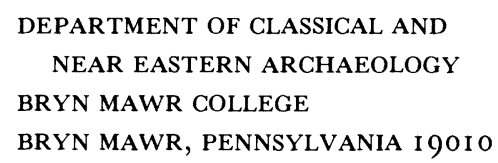

\footnotetext{
${ }^{62}$ I have omitted from my survey the countless, modest dedications of terracotta vases, limbs, wombs, and figurines made by women at many Greek sanctuaries, not only those of Hera and other female deities, such as the Nymphs, but
}

also of healing gods such as Asklepios and Amphiaraos. These are usually not inscribed and often undatable; moreover, their relative inexpensiveness makes them uninformative in terms of women's social position. 